\section{在来工法木造住宅の振動特性と 耐震診断評点との関係}

\section{RELATIONSHIP BETWEEN DYNAMIC CHARACTERISTICS AND SEISMIC DIAGNOSIS FOR CONTEMPORARY TIMBER HOUSES}

\author{
入江康隆 — * 1 野俣善則 — $* 2$ \\ キーワード : \\ 在来工法木造住宅, 建設現場調査, 常時微動測定, 固有振動数, \\ 減衰定数, 層間㧖れ角, 耐震診断
}

Keywords:

Contemporary timber house, Construction site survey, Microtremor measurement, Natural frequency, Damping coefficient, Torsional angle betweem upper and lower floors, Seismic diagnosis

\section{Yasutaka IRIE $-* 1 \quad$ Yoshinori NOMATA $-* 2$}

In order to apply the results of microtremor measurements and construction site surveys to seismic diagnosis of contemporary timber seismic diagnosis. The main results obtained from these investigations are as follows.

Timber houses having large translational frequency and damping coefficient, are estimated high quality from the viewpoint of seismic diagnosis. The torsional angle between upper and lower floors, and the torsional frequency of timber houses have a slight correlation with the grade of seismic diagnosis. houses, we investigate the relation between dynamic characteristics and

\section{1.はじめに}

耐震診断では，既存の木造住宅を対象にして，耐力要素や接合部な どの各仕様から終局強度時の耐震性能を評価している1)。しかし, 既 存住宅では, これらの耐震診断の対象となる要素は仕上げ材の下に隠 れているため，仕様の多くが不明であり精確な評価をするのは困難であ る。一方, 建物の振動特性を求める方法に, 常時微動波形を用いる 方法があり，これは既存住宅においても容易に可能なので，この結果 を耐震診断に応用ができれば好都合である。

このような意図で, 既存木造住宅の常時微動測定結果から耐震診断 一の応用を目指した研究に，例えば文献 2),3)がある。これらの対象住 宅は，文献 2)では 238 棟，文献 3)では 244 棟（微動測定は 5 棟）と 資料数は多いが，住宅個々の情報量が不足なものが多いため診断結 得られていない。筆者等は, 十年来, 住宅の建設現場調查, および 常時微動測定を行っている ${ }^{4)}$ が，質量調査まで含む精確な調査とはい えず，また，常時微動も㧖れ成分までを含めた十分な測定ではなかっ た。

本論文は，資料不足による耐震診断の不確かさを，詳細な常時微動 測定により補うための基礎資料を提供するものである。この際，建築年 による使用材料の劣化，仕様・工法に関する不確かな情報から生じる 診断のバラツキを排除するため，もともと既存住宅を対象とする耐震診断 を，新築住宅のみに限定する。また，同一建設現場を数度訪問するこ とで, 柱梁寸法, 筋交い, 合板の取り付け, その他の部材の種類, 数量, さらに施工方法までを綿密に調查する。ところで, 耐震診断は, 住宅の保有水平耐力の診断のみで, 減衰性能に関寸る評価は行って いないが, 耐震診断評点は間接的に減衰性能も含めた耐震性能を表 す総合指標とみなし, 診断結果と常時微動測定から得られる振動特性 との関係を求める。これらの住宅について, 質量, 壁配置などの基礎 情報, および振動特性と耐震診断評点との間の相関関係を検討するこ とで，建設現場調查，常時微動測定の耐震診断一の活用を目指そうと するものである。 果と振動特性（並進固有振動数）との関係は大きくばらつき良い相関は

\section{2. 調査・測定住宅概要}

\section{(1)住宅概要}

宇都宮市内の在来工法木造住宅を対象として, 同一現場を数度訪れ, 部材レベルの詳細な現場調查を行った。調查期間は 2007 年 9 月から 2008 年 11 月の延べ 43 日。その内，竣工間近の 8 棟で常時微動測 定を行った。調査住宅の概要を, 表 1 に示寸。質量 $\mathrm{MRF}_{\mathrm{RF}}, \mathrm{M}_{2}, \mathrm{M}_{1}$ は, 構成部材の材積に材種を考慮した密度を掛けて求め, 階高中央を境に 床位置，小屋位置にまとめたものである。

\section{(2)測定概要}

測定サンプリング周波数は $100 \mathrm{~Hz}$ で，測定時間は約 10 分である。住 宅の並進，据れ，および地盤の振動特性を得る目的で，図 1 に示寸 換振器配置による $12 \mathrm{ch}$ 同時測定を行った。

\section{表 1 住宅概要}

\begin{tabular}{|c|c|c|c|c|c|c|}
\hline \multirow{2}{*}{$\begin{array}{c}\text { 住宅 } \\
\text { No. }\end{array}$} & \multirow{2}{*}{ 屋根葷き材 } & \multicolumn{2}{|c|}{ 床面積 $\left(\mathrm{m}^{2}\right)$} & \multicolumn{3}{|c|}{ 質量 $\left(\mathrm{kN} \cdot \mathrm{s}^{2} / \mathrm{m}\right)$} \\
\hline & & $\mathrm{S}_{2}$ & $\mathrm{~S}_{1}$ & $M_{R F}$ & $\mathrm{M}_{2}$ & $M_{1}$ \\
\hline 1 & 瓦莫き & 89.85 & 124.66 & 22.2 & 26.66 & 84.63 \\
\hline 2 & スレート葷き & 68.59 & 66.52 & 8.91 & 11.45 & 51.57 \\
\hline 3 & 瓦莫き & 57.55 & 91.5 & 10.97 & 18.73 & 75.7 \\
\hline 4 & ガルバリウム鋼板 & 46.37 & 46.37 & 6.83 & 8.47 & 33.38 \\
\hline 5 & 瓦莫き & 104.34 & 110.14 & 16.79 & 18.82 & 74.68 \\
\hline 6 & ガルバリウム鋼板 & 71.22 & 71.22 & 9.11 & 12.65 & 50.27 \\
\hline 7 & ガルバリウム鋼板 & 64.1 & 90.8 & 6.86 & 16.62 & 52.08 \\
\hline 8 & ガルバリウム鋼板 & 72.87 & 72.87 & 9.23 & 13.16 & 52.16 \\
\hline
\end{tabular}
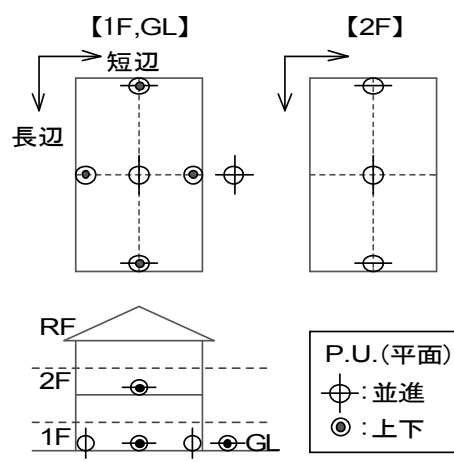

図 1 換振器配置

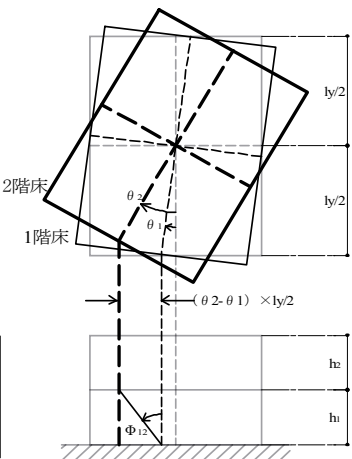

図 3 層間㨝れ角

\footnotetext{
宇都宮大学大学院学際先端システム学専攻 准教授・工博

（干 321-8585 宇都宮市陽東 7-1-2）
}

宇都宮大学 技術専門職員 


\section{3、木造住宅の振動特性}

(1)波形，スペクトル，スペクトル比

住宅 No.5 について，測定波形とそのフーリエスペクトル，スペクトル 比および位相差とを図 2 に示す。図中， $\theta_{1} ， \theta_{2} ， \quad \phi 12$ は，前ペー ジの図 3 に示すように, $\theta_{1}, \theta_{2}$ は, 各階において両端部の水平変 位の差を換振器間距離で除して求めた 1 階, 2 階の平面内㧖れ角, $\phi$ 12 は, 各階平面内㧖れ角の差により建物端部で生じる捩れ変形を階高 で除して次式により求めた層間据れ角である。

$$
\phi_{12}=\left(\theta_{2}-\theta_{1}\right) \frac{l_{y}}{2 \times h_{1}}
$$

解析は静穏な 1 区間 20.48 秒を 6 区間用いて行った。住宅の応答は 測定サイトの状況の影響を受ける。そこで, サイトごとの 1 階での並進 応答波形の大きさを揃えることにする。すなわち, 各サイトにおいて約 120 秒間の測定波形を用い, ピーク時刻毎の振幅值の平均から 1 階平 均振幅を求め, これらの比率で, 式(1)で得られた結果を除すことでサ イト間の入力の大きさの補正を行った（表2（ ）内の值）。スペクトル の平滑化はパルゼンのウインドウ幅を $0.2 \mathrm{~Hz}$ として行った。

(2)並進固有振動数

スペクトル比（2 階/1 階）において卓越している振動数より，ロッキ ングを含む建物固有振動数を求めることができる。この振動数を建物系 固有振動数と称して求めた。スペクトルの卓越が不明確な場合には, 位 相遅れが $\pi / 2$, または $-\pi / 2$ 程度になる振動数を目安にして定めた (図2の上から 5,6 段目の図参照)。

\section{(3) 掘れ固有振動数}

図 2 の 7,8 段目の $\theta_{1} ， \quad \theta_{2}$ のスペクトル，および $\phi 12$ のスペクトル と位相差から， $13.9 \mathrm{~Hz}$ 附近から， 1， 2 階が $\pi / 2$ ，または $-\pi / 2$ の 位相差になり位相が乱れることから，この振動数を㧖れ固有振動数と定 めた。

(4)減衰定数

減衰定数は，並進波形のスペクトル比の卓越振動数における曲線か ら，1/ $\sqrt{2}$ 法を用いて求めた。

以上のようにして求めた振動特性の結果を, 表 2 にまとめて示す。対 象住宅 8 棟における平均值は, 並進固有振動数 $7.5 \mathrm{~Hz}$, 㧖れ固有振 動数 $10.1 \mathrm{~Hz}$ ，層間㧖れ角 $2.8 \times 10^{-8} \mathrm{rad}$, 減衰定数 $2.7 \%$ であった。

\section{4.木造住宅の振動特性と診断評点の関係}

(1)木造住宅の耐震診断

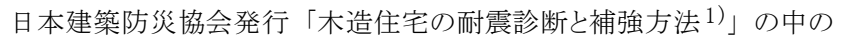
「精密診断法 1 (保有耐力診断法)」に従い, 図面や現場調查の情報 に基づき，住宅 8 棟の耐震診断を行った。

診断評点の算出に際しては, さまざまな要因を考慮し低減係数をかけ るが，対象住宅が新築なので，偏心率による低減のみを考慮する。耐 力要素の評価は，文献1)で規定されている壁強さ係数に基づく。

(2)住宅の基礎情報の活用

住宅の振動特性と耐震診断評点との関係を検討する前に，振動特性 に密接な関係がある住宅の基礎情報（床面積, 質量, 耐力壁の配置 バランスなど）と振動特性との関係について，まとめる。

1 階床面積に対する 2 階床面積の比 $\left(\mathrm{S}_{2} / \mathrm{S}_{1}\right), 2$ 階床位置質量に対 する小屋位置質量の比 $\left(\mathrm{MRF}_{\mathrm{RF}} / \mathrm{M}_{2}\right)$ と並進固有振動数との関係を, それぞ れ, 図 4 , 図 5 に示す。図 4 からは, 相関はほとんど見られない。図
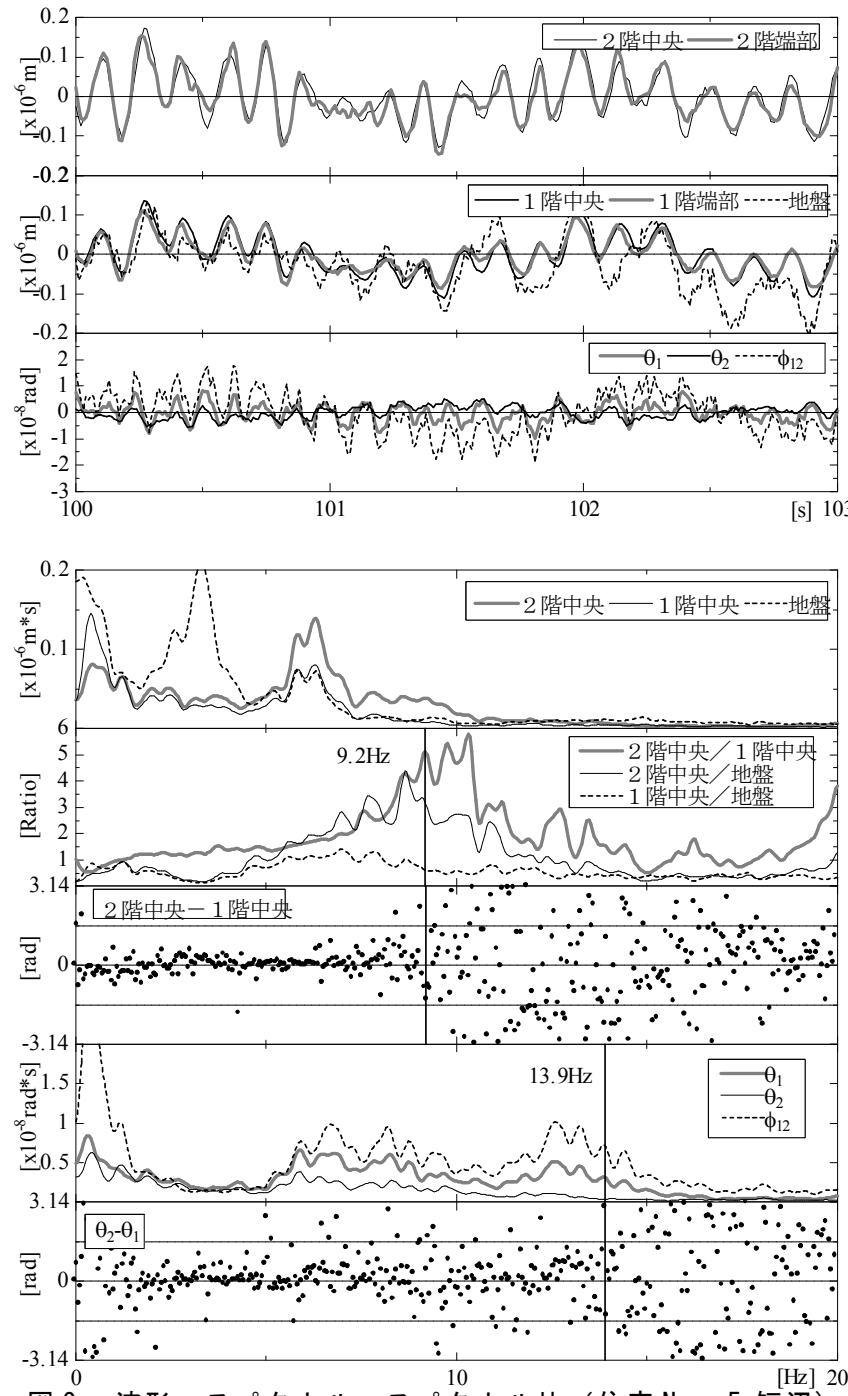

図 2 波形，スペクトル，スペクトル比（住宅 No．５短辺）

表 2 振動特性のまとめ

\begin{tabular}{|c|c|c|c|c|c|c|c|c|c|}
\hline \multirow{2}{*}{$\begin{array}{l}\text { 住宅 } \\
\text { No. }\end{array}$} & \multicolumn{2}{|c|}{ 並進固有振動数 (Hz) } & \multirow{2}{*}{$\begin{array}{c}\text { 读扎固有 } \\
\text { 振動数 } \\
(\mathrm{Hz}) \\
\end{array}$} & \multirow{2}{*}{\multicolumn{2}{|c|}{$\begin{array}{c}1 \text { 階平均振幅 (比率) } \\
\left(10^{-6} \mathrm{~m}\right) \\
\end{array}$}} & \multirow{2}{*}{\multicolumn{2}{|c|}{ 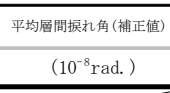 }} & \multicolumn{2}{|c|}{ 減衰定数(\%) } \\
\hline & 短边 & 長辺 & & & & & & 短辺 & 長辺 \\
\hline 1 & 6.4 & 5.8 & 1 & 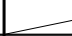 & & 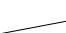 & & 2.1 & 2. 2 \\
\hline 2 & 6.1 & 7.5 & 9.0 & 0.021 & $(0.11)$ & 1. 377 & $(12.05)$ & 2.9 & 1.6 \\
\hline 3 & 7.2 & 7.9 & 11.2 & 0.102 & $(0.55)$ & 3.403 & $(6.20)$ & 2.8 & 3.0 \\
\hline 4 & 4.9 & 5.9 & 9.1 & 0.563 & $(3.04)$ & 3. 251 & $(1.07)$ & 1.1 & 1.2 \\
\hline 5 & 9.2 & 8.0 & 13.9 & \begin{tabular}{|l|l}
0.063 \\
\end{tabular} & $(0.34)$ & 1. 557 & (4. 54) & 3.1 & 2. 9 \\
\hline 6 & 10.1 & 8.9 & 8.4 & \begin{tabular}{|l}
0.085 \\
\end{tabular} & $(0.46)$ & 2. 590 & $(5.66)$ & 3.3 & 2.7 \\
\hline 7 & 7.9 & 8.9 & 11.4 & 0.319 & $(1.72)$ & 1. 805 & $(1.05)$ & 4. 0 & 3.8 \\
\hline 8 & 7.0 & 8.4 & 7.9 & 0.143 & $(0.77)$ & 5.699 & $(7.38)$ & 3.1 & 3.4 \\
\hline 平均 & 7.4 & 7.7 & 10.1 & 0.185 & $(1.00)$ & 2. 812 & $(2.81)$ & 2.8 & 2.6 \\
\hline
\end{tabular}

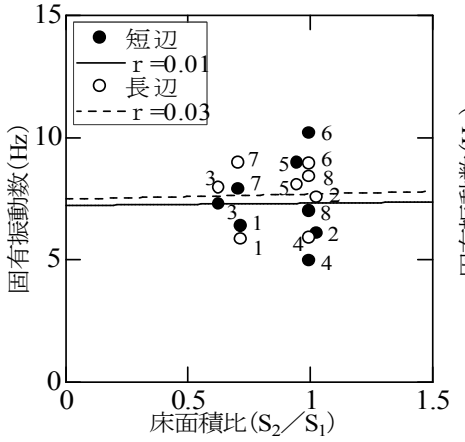

図 4 床面積比と固有振動数

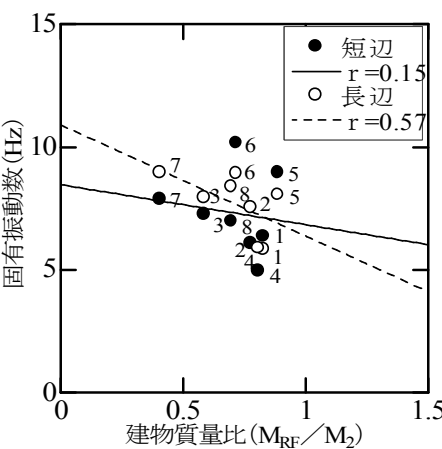

図 5 建物質量比と固有振動数 
5 から，質量比が 1 に近くなるほど，才なわち総 2 階に近づくほど，固 有振動数が低くなる傾向が認められる。

そこで，この建物質量比と精密診断評点（以降，単に診断評点）と の関係を求めて，図6に示す。これによると，質量比が1（総2階建て） に近づくと，診断評点が下がる傾向にあることが分かる。

以上のように，バラツキはあるが，住宅の $1 ， 2$ 階の質量比の違いは 診断評点に影響を及ぼす。これ以外にも影響を及ぼす要因として考え られるのは，屋根莫き材料， 住宅規模（床面積）， 1， 2 階の用途（1 階居間で2階個室群，あるいはその逆）などがある。これらの要因の うち，振動特性，診断評点に最も影響を及ぼすと考えられる屋根莫き 材料の違いで対象住宅を区分し，瓦葺き住宅は 3 棟のみと少ないこと から，非瓦莫き住宅 5 棟についてのみ振動特性と診断評点との関係を 求める。以下の図において, 図中の数字は住宅番号に対応し, 近似 直線は非瓦莫き住宅の夕についての関係を示す。

(3)並進固有振動数と診断評点の関係

並進方向固有振動数と診断評点との関係を図7 7 示す。短辺および 長辺方向ともに、固有振動数が大きい住宅ほど、診断評点が高くなる 傾向が見られる。図中の近似直線は，実線が1階，破線が2階につ いての関係を表し，相関係数は $0.53 \sim 0.94$ と高い。並進方向固有振 動数と 1 階における診断評点の関係式を、以下に示す。ちなみに，屋 根莫き材料を区別せず，全 8 棟で求めた相関係数は， $0.47 \sim 0.82$ で あった。

[短辺] $I_{f}=0.42 \times f-0.56$ 相関係数: 0.94 (2) [長辺] $I_{f}=0.27 \times f+0.46$ 相関係数: 0.73 (3) $I_{f}$ : 診断評点, $f$ : 並進方向固有振動数 $(H z)$

(4)減衰定数と診断評点との関係

精密診断では，建物の減衰性能に関寸る評価は行っていない。しか し，「はじめに」でも述べたように，耐震診断評点を建物の耐震性能 を表す総合指標と考え，この評点と減衰定数との関係を求め, 図8に 示す。短辺および長辺方向ともに、減衰定数が大きい住宅ほど、診 断評点が高くなる傾向が見られる。図中の近似直線は, 実線が1階, 破線が2階の診断評点で，相関係数は $0.63 \sim 0.89$ と高い。減衰定数 と 1 階における評点の関係式を、以下に示す。ちなみに，全 8 棟で 求めた相関係数は, $0.32 \sim 0.78$ であった。

[短辺] $I_{h}=50.12 \times h+0.98$ 相関係数: 0.63

[長辺] $I_{h}=37.17 \times h+1.63$ 相関係数 : 0.86

$$
I_{h}: \text { 診断評点, } h \text { : 減衰定数 }
$$

(5)偏心率と㧖れ固有振動数との関係

偏心率と捩れ固有振動数との関係を, 図9 に示す。㧖れ固有振動数 には, 短辺, 長辺の区別はないが診断評点は短辺, 長辺の区別をし ているので, 図は短長辺で別々に表示している。短辺方向非瓦 2 階 においては，相関は見られないが，その他の場合には，偏心率の低 下に伴い，据れ固有振動数が大きくなる傾向が見られるが，相関係数 は高くない。ちなみに，屋根葺き材料を区別しないで求めた相関係数 は $0.36 〜 0.49$ であった。

(6)偏心率と層間掘れ角との関係

偏心率と層間㨭れ角との関係を，図 10 に示す。偏心率が大きい住 宅ほど, 層間㧖れ角が大きくなる傾向が見られる。相関係数は，0.17 〜 0.54 と高くはない。ちな子に, 全 8 棟で求めた相関係数は, 0.40 程 度であった。
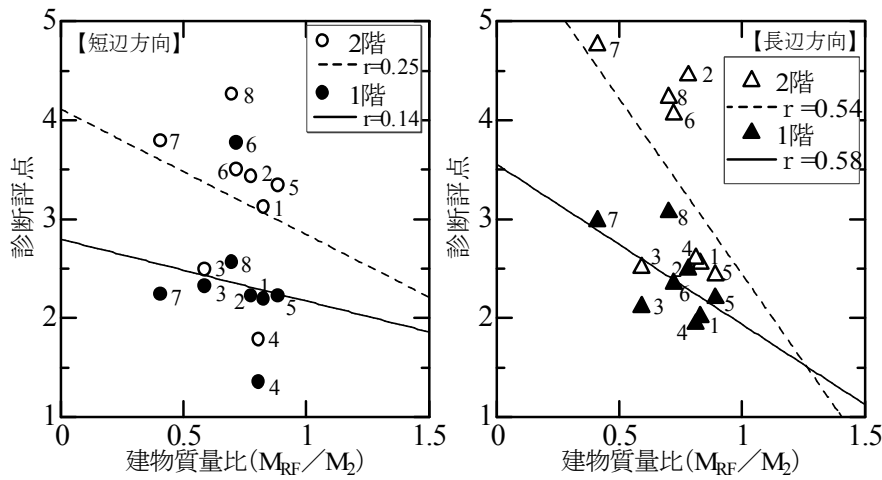

図 6 建物質量比と診断評点

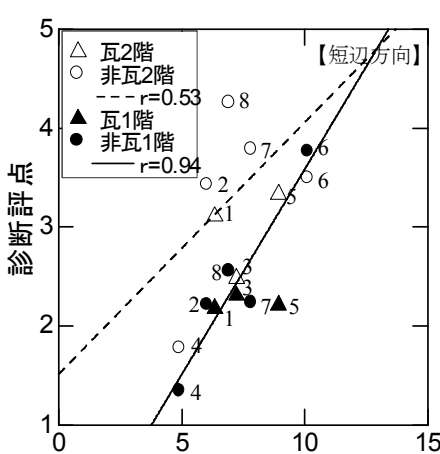

固有振動数 $(\mathrm{Hz})$

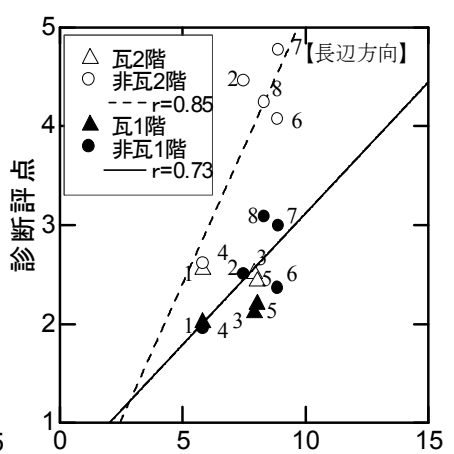

固有振動数 $(\mathrm{Hz})$
図7 並進固有振動数と 診断評点
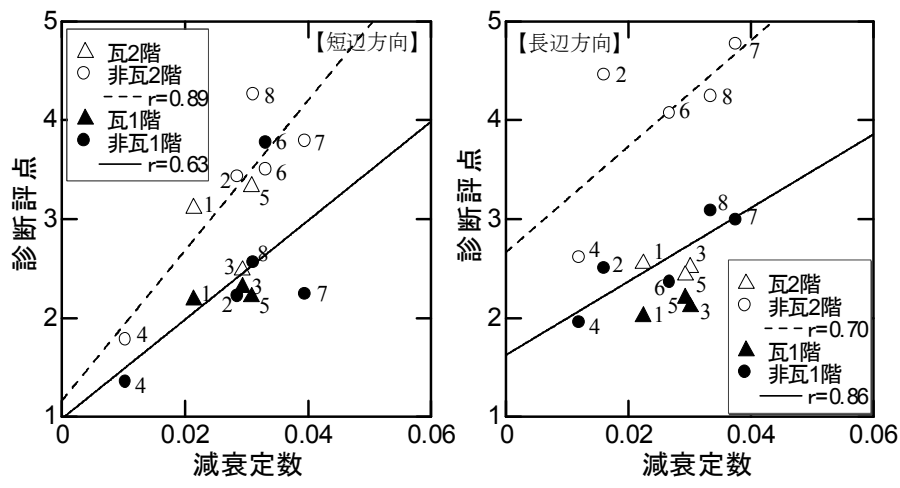

図8 減衰定数と 診断評点
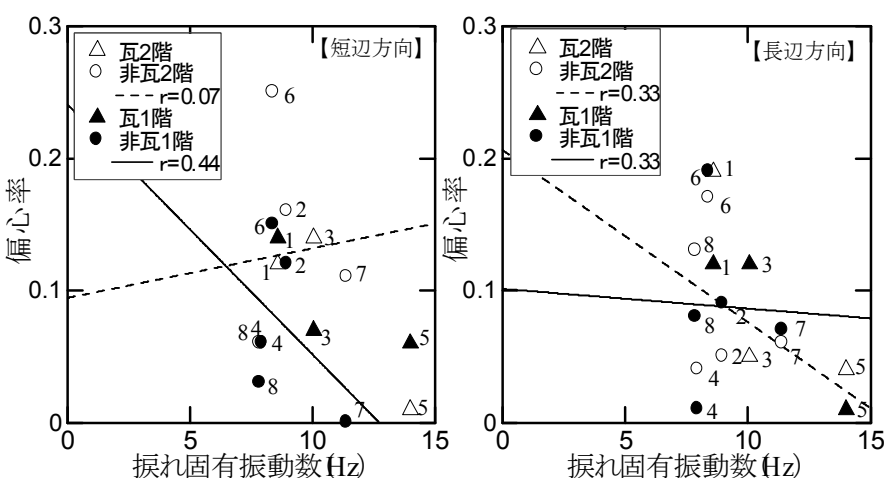

図 9 㨭れ固有振動数と偏心率 
(7)偏心率, 層間㨭れ角, 㧖れ固有振動数之診断評点の関係 㧖れ振動に関して, (5),(6)で検討した偏心率, 層間㨭れ角, 据れ固有 振動数と評点の関係を, 図 11 ～図 13 に示す。いずれの図からも, 高 い相関性は読み取れない。図 11 については, 例えばNo.6 は, 西, および，北面にはほとんど開口部がなく耐力壁が張りめぐらされている ため, 偏心率は大きいが, 診断評点は高い, No.4 は, 耐力壁の配 置バランスが良いので壁量はそれほどでもなく診断評点は低いなど, 様々であるためである。図 12 については, 層間据れ角の大きさは, 感 覚的には耐力壁量に反比例するので, 診断評点は小さくなるものと予 想したが，そのような結果にはなっていない。図 13 については，㨭れ 固有振動数の高さは捩れにくさの指標となり, その結果が診断評点に 反映されるものと考えたが, 図 13 左の 1 階においては, そのような結果 になっていない。

\section{5.まとめ}

建設中の住宅8棟について, 図面, 詳細な現場調査と竣工間近の常 時微動測定から, 振動特性と精密診断の診断評点との関係を求めた結 果，以下のことが分かった。

(1)並進固有振動数が大きい住宅ほど, 診断評点は高い(図7)。

(2)減衰定数が大きい住宅ほど, 診断評点は高い(図8)。

(3)㧖れ振動特性の指標である偏心率, 層間㨭れ角, 捩れ固有振動数 と診断評点の間の有意な関係は認められない。(図 11,12,13)。

上記(1),(2)については，すでに報告があり，著者等も確認している。 これについては, 診断評点のバラツキが小さいので, 高い相関性を得 ることができた。(3)については以下のような理由が考えられる。

まずは, 調查棟数が8棟と少なかったこと。次に, ここでは, 単独の 振動特性と住宅の総合評価を示寸診断評点との 1 対 1 の関係にしか着 目していないこと, 寸なわち, 複数の要因との関係にも着目する必要が あること。さらに, 対象住宅の同質性, 寸なわち, 屋根莫き材料, 床 面積, 床面積比, 質量比, 1, 2 階の用途 (1階居間, 2階個室群) などがまちまちであったことなどである（表 1)。また，㧖れの詳細な測定 を意図しながら, 屋階, 寸なわち, 小屋裏構面での測定が, 現場状 況, 危険などの理由からできなかったことで, 層間据れを1階床と2階床 間で評価せざるをえなかったことも一因である。

今後は, 調查棟数を増やすとともに, 同規模で同質の住宅について 資料を揃えた検討を行い, 診断評点との間のさらに精度の高い関係を 求める心゙く, 継続して研究を行っていくつもりである。

\section{謝辞}

測定, 調查を許可してくださった施主の方々，および，測定，調查に 参加した研究室の大学院生, 学部生に深く感謝いたします。

\section{参考文献}

1) 木造住宅の耐震診断と補強方法，（財）日本建築防災協会，2004。 2）田端千夏子, 大橋好光 : 微動測定とその耐震診断への応用の可能性, 日 本建築学会構造系論文集，第 616 号，pp141-147，2007年 6 月.

3）馬場章子, 藤田香織, 饗庭伸, 佐藤弘美 : 神田地区における既存木造戸 建て住宅の耐震性能評価, 日本建築学会大会学術講演梗概集, C-1 構造 III , pp263-264, 2006. 9

4) 入江康隆: 建設段階に伴う 2 階建て在来工法木造住宅の振動特性の変 遷, 構造工学論文集, Vol. 44B, pp463-470, 1998. 3
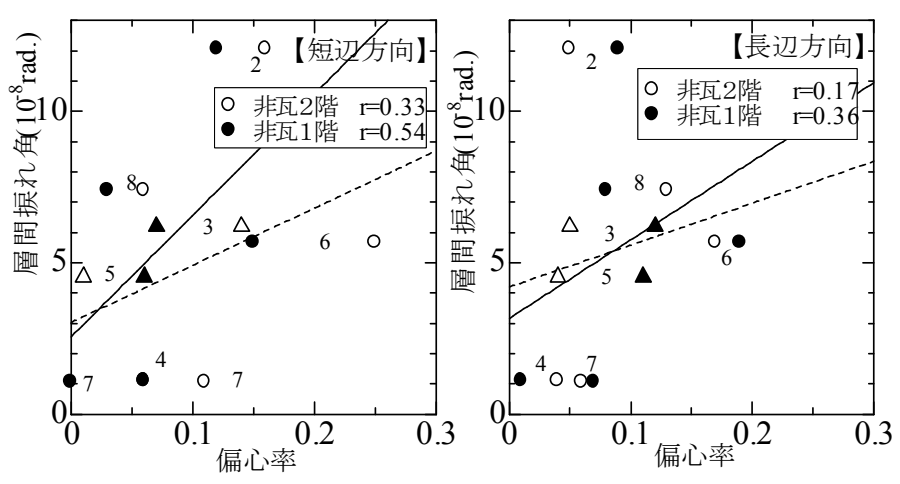

図 10 偏心率と層間㧖れ角
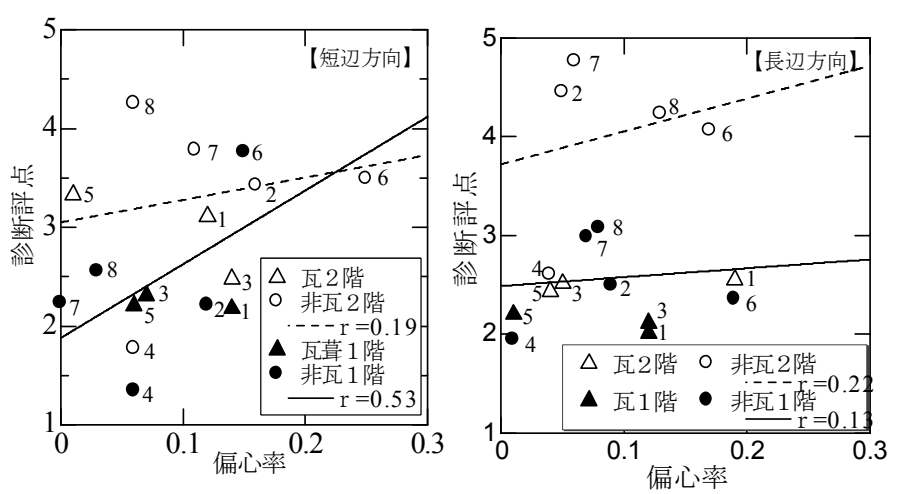

図 11 偏心率と診断評点
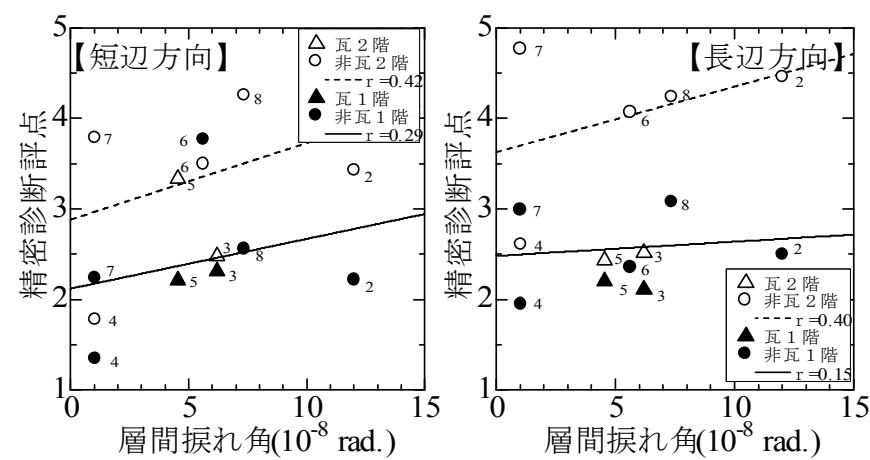

図 12 層間据れ角と診断評点
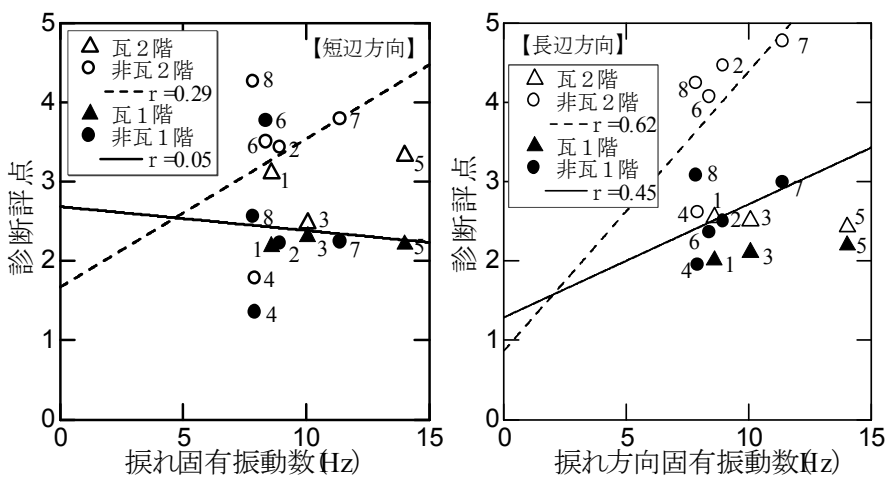

図 13 据れ固有振動数と診断評点

[2009 年 6 月 19 日原稿受理 2009 年 8 月 28 日採用決定］ 